\title{
Evaluasi Pelaksanaan Program Pendidikan Inklusi di SMP Negeri
}

\author{
Eni Mariani \\ Magister Manajemen Pendidikan Universitas Kristen Satya Wacana \\ enimariani88@gmail.com \\ Bambang Suteng Sulasmono \\ Magister Manajemen Pendidikan Universitas Kristen Satya Wacana \\ sulasmonobambang@yahoo.com
}

\begin{abstract}
This study aims to evaluate the design, installation, process, and products of the inclusive education program implementation in a Salatiga Public Middle School. This type of research is program evaluation with a discrepancy evaluation model. Information sources in this study are the Principal, Local Content Teacher, Counseling Guidance Teacher who also acts as Special Facilitators Teacher (GPK). Data collection technique include interviews, observation and document study. Data analysis technique include data collection, data reduction, data presentation, and conclusion drawing. Data validation through technical and source triangulation. The results: (1) the design evaluation showed the general curriculum and assessment plans have not been modified, educators do not yet have adequate competence, facilities and infrastructure do not yet support the needs of special needs student (ABK); (2) the installation evaluation showed there is no entrance test, the learning design and assessment have not considered the existence of $A B K$, funding is taken from BOS funds and support from some $A B K$ parents; (3) the process evaluation showed the ABK have difficulty following learning, the support from the community and agencies has not been maximized; and (4) the product evaluation showed that student learning outcomes, namely the assessment of student ID cards are still equated with normal students. Based on the results of the evaluation, the researchers gave the following recommendations: 1) Teachers and GPK collaborated in developing curriculum and competencies, 2) Principals and teachers collaborated in designing models and technical instructions to handle $A B K$, as well as increasing collaboration with several agencies, and 3) The education office needs to pay attention to the implementation of inclusive education programs and provide assistance in the form of costs, training, seminars, and fulfillment of facilities and infrastructure.
\end{abstract}

Keywords: Discrepancy Evaluation Model, Inclusion Education, Program Evaluation

\section{Article Info}

Received date: 1 Agustus $2018 \quad$ Revised date: 22 Desember $2018 \quad$ Accepted date: 22 Desember 2018

\section{PENDAHULUAN}

Dalam Undang-undang Nomor 20 Tahun 2003 tentang Sistem Pendidikan Nasional, pasal 5 antara lain ditentukan bahwa setiap wagra negara memperoleh hak yang sama untuk memperoleh pendidikan yang bermutu, dan warga negara yang memiliki bakat istimewa dan kelainan fisik, emosional, intelektual dan sosial berhak mendapatkan pendidikan khusus. Lebih lanjut Permendiknas No 70 Tahun 2009 tentang Pendidikan Inklusi menentukan bahwa siswa yang memiliki bakat atau kecerdasan istimewa serta siswa yang memiliki keterbatasan fisik, sosial, emosional 
Kelola: Jurnal Manajemen Pendidikan, Vol. 5, No. 2, Juli-Desember 2018

dan mental dapat mengikuti pendidikan secara bersama-sama dengan siswa pada umumnya.

Pendidikan inklusi merupakan sistem pendidikan yang terbuka bagi semua siswa baik siswa normal, memiliki bakat khusus dan siswa yang memiliki kekurangan. Pelaksanaan pembelajaran dalam pendidikan inklusi disesuaikan dengan kebutuhan siswa. Pendidikan inklusi dapat menjadi jembatan untuk mewujudkan pendidikan untuk semua (education for all/EFA), tanpa ada seorangpun yang tertinggal dari layanan pendidikan (Kustawan, 2012: 7). Pendidikan inklusi adalah sistem layanan pendidikan yang mensyaratkan anak berkebutuhan khusus (ABK) belajar di sekolah-sekolah terdekat di kelas biasa bersama-sama teman seusianya. Sekolah penyelenggara pendidikan inklusi adalah sekolah yang menampung semua murid di sekolah yang sama. Sekolah ini menyediakan program pendidikan yang layak dan menantang, tetapi disesuaikan dengan kemampuan dan kebutuhan setiap murid maupun bantuan dan dukungan yang dapat diberikan oleh para guru agar anak-anak berhasil (Wathoni, 2005: 101). Hal ini juga diungkapkan oleh Kustawan (2012: 7) yang menyatakan bahwa pendidikan inklusi adalah sistem pendidikan yang terbuka bagi semua individu serta mengakomodasi semua kebutuhan sesuai dengan kondisi masingmasing individu. Dapat disimpulkan bahwa pendidikan inklusi adalah suatu sistem layanan pendidikan yang mensyaratkan anak berkebutuhan khusus untuk belajar di sekolahsekolah terdekat, yang terbuka bagi semua serta tidak membeda-bedakan latar belakang kehidupan anak. Sekolah penyelenggara pendidikan inklusi adalah sekolah yang menampung semua murid, mengakomodasi murid baik karena keterbatasan fisik maupun mental, serta sekolah yang juga menyediakan program pendidikan layak dan menantang, disesuaikan dengan kemampuan dan kebutuhan masing-masing individu.
Dalam pelaksanaannya, pendidikan inklusi memerlukan penyesuaian dan fleksibilitas di berbagai bidang, baik bidang pendidikan, pengajaran, sosial, perilaku maupun budaya. Oleh karena itu dalam proses pembelajaran pendidikan inklusi harus ada kesesuaian antara kurikulum, pendekatan pembelajaran, proses pembelajaran dan sistem evaluasi dengan kondisi siswa. Sehingga kurikulum nasional harus dimodifikasi sedemikian guna menyesuaikan dengan kebutuhan siswa. Hal ini dilakukan agar anak berkebutuhan khusus dapat mengikuti pembelajaran seperti siswa normal lainnya. Dalam modifikasi kurikulum itu diperlukan kerjasama antara guru, guru pembimbing khusus/GPK, orangtua, para professional dan peserta didik. Kerjasama dilakukan untuk memodifikasi program kerja, penetapan tujuan, isi, strategi, metode pembelajaran, organisasi kelas, assesmen, evaluasi, komunikasi dan pembiayaan (Muftuhatin, 2014: 208).

Tujuan penyelenggaraan pendidikan inklusi menurut Alfian (2013: 75) adalah:

1) untuk memberikan kesempatan seluasluasnya bagi anak berkebutuhan khusus untuk mendapatkan pendidikan yang layak,

2) membantu mempercepat program wajib belajar pendidikan dasar,

3) membantu meningkatkan mutu pendidikan dengan menekan angka tinggal kelas dan putus sekolah,

4) menciptakan pendidikan yang menghargai keanekaragaman, tidak diskriminatif dan ramah terhadap pembelajaran.

Sedang karakteristik pendidikan inklusi menurut Zakia (2015) adalah:

1) pendidikan inklusi merupakan wujud usaha merespon keragaman individu,

2) pendidikan inklusi untuk mengatasi hambatan-hambatan anak dalam belajar,

3) pendidikan inklusi membawa anak untuk belajar yang bermakna dalam hidup, 
4) pendidikan inklusi untuk anak-anak marginal, esklusif dan membutuhkan pendidikan khusus.

Sekolah yang menyelenggarakan program pendidikan inklusi harus memenuhi standar kualifikasi yang telah ditentukan dan para gurunya pun harus memiliki kompetensi dalam menangani anak berkebutuhan khusus. Guru yang berperan dalam pelaksanaan program pendidikan meliputi guru kelas, guru mata pelajaran, dan guru pembimbing khusus (GPK) (Kemendikbud. 2012: 43; Kustawan, 2012:73). Dalam hal sarana dan prasarana Kustawan (2012) mengatakan bahwa sebagai penyelenggara pendidikan inklusi hendaknya sekolah menyediakan sarana dan prasarana yang memadai untuk menjamin kebutuhan siswa dan agar anak berkebutuhan khusus dapat mengikuti pembelajaran dengan siswa normal lainnya. Permendiknas No 70 Tahun 2009 pasal 11 juga memberikan ketentuan bahwa sekolah harus menyediakan sarana dan prasarana yang aksesibel agar anak berkebutuhan khusus dapat mengikuti pembelajaran dengan baik.

Sistem assesmen pembelajaran seharusnya dirancang untuk mengetahui kondisi siswa, di mana assesmen pembelajaran meliputi tahap perencanaan, pengumpulan informasi untuk mencapai hasil belajar, pelaporan dan penggunaan informasi hasil belajar siswa. Assesmen meliputi penilaian tertulis, sikap, kinerja atau produk, portofolio dan unjuk kerja. Dalam Permendiknas No 70 Tahun 2009 juga ditentukan bahwa anak berkebutuhan khusus yang menyelesaikan pendidikan berdasarkan kurikulum yang dikembangkan oleh satuan pendidikan dibawah standar nasional pendidikan mendapat surat tanda tamat belajar yang blangkonya dikeluarkan oleh Sekolah yang bersangkutan.

Dalam Permendiknas No 70 Tahun

2009 ditentukan pula bahwa biaya penyelenggaran pendidikan inklusi menjadi tanggung jawab bersama antara pemerintah, masyarakat dan orangtua. Masyarakat dan orangtua harus berperan untuk mendukung pendidikan, karena pendidikan merupakan tanggung jawab bersama. Masyarakat harus berperan dalam perencanaan, penyediaan tenaga ahli, pengambilan keputusan, pelaksanaan pembelajaran, pendanaan, pengawasan dan penyaluran lulusan. Dalam penyelenggaraan program pendidikan inklusi Sekolah dapat bekerjasama dan membangun jaringan dengan satuan pendidikan khusus, perguruan tinggi, organisasi profesi, lembaga rehabilitasi, rumah sakit, pusat kesehatan masyarakat, terapi klinik, LSM dan masyarakat (Permendiknas No 70 Tahun 2009).

Praktik penyelenggaraan pendidikan inklusi telah menarik perhatian sejumlah peneliti. Mitiku, dkk (2014: 118) misalnya menemukan bahwa walaupun ada beberapa peluang yang mendukung pendidikan inklusi, hal itu tidak dapat dianggap sebagai jaminan karena kurangnya kesadaran, komitmen, dan kerjasama. Serta ada tantangan nyata yang menghambat implementasi penuh dari pendidikan inklusif. Secara umum dapat disimpulkan bahwa tantangan lebih besar daripada kesempatan pada implementasi penuh dari pendidikan inklusif dan harus ada kerjasama yang kuat antar pemangku kepentingan, LSM, dan badan-badan yang bersangkutan untuk mewujudkan pendidikan inklusi.

Di Indonesia Sunardi, dkk (2011: 1) menemukan bahwa kebanyakan sekolahsekolah telah mengembangkan rencana strategis (untuk program inklusif), namun masih banyak sekolah yang belum menata ulang struktur organisasi mereka. Peneliti lain, Sari (2012: 190), juga menemukan bahwa pelaksanaan inklusi di SD Negeri tempat penelitiannya, tidak berjalan sebagaimana mestinya. Oleh karena itu peneliti menyarankan agar para guru, GPK, kepala sekolah memang benar-benar melakukan tanggung jawabnya dan tahu tugasnya sebagai penyelenggara sekolah inklusi. 
Di lain pihak Sartica dan Ismanto (2016: 49), menemukan bahwa program pendidikan inklusi di lokasi penelitian mereka sudah memenuhi kebutuhan siswa, fasilitas khusus memang tidak mencukupi bagi anak berkebutuhan khusus, kompetensi guru cukup baik, belajar secara umum dengan memperhatikan setiap individu, prestasi akademik dan non akademik siswa dengan kebutuhan khusus cukup baik. Muftuhatin (2014: 201) juga menemukan bahwa evaluasi pembelajaran sudah cukup bagus karena guru sudah menerapkan dua metode dalam evaluasi yaitu dengan soal yang disamakan dengan reguler dan yang kedua dengan soal sesuai dengan kebutuhan mereka, disertai dengan portofolio yang mencatat perkembangan mereka selama pembelajaran. Sementara Lukitasari, dkk (2017:121) menemukan bahwa dampak positif kebijakan pendidikan inklusi di kota penelitian mereka terlihat dari meningkatnya jumlah peserta didik $A B K$ di sekolah regular dari tahun ke tahun dan berkurangnya diskriminasi yang dialami siswa ABK oleh teman sebaya, guru dan masyarakat.

Hasil penelitian yang sedikit berbeda ditemukan oleh Widyawati (2013: 109) di mana sekolah sudah mendapat izin dan juga panduan untuk melaksanakan program inklusif, namun infrastruktur khusus tidak memadai, sementara kurikulum sudah dimodifikasi. Kompetensi guru cukup memadai dalam menangani anak dengan kebutuhan khusus, sementara pendanaan pendidikan inklusi hanya mengandalkan dana BOS, dan tidak ada pemantauan terus menerus dari departemen pemerintahan terkait. Anak berkebutuhan khusus yang berprestasi dan tidak berprestasi sudah dilayani dengan baik.

Dari berbagai hasil penelitian diatas maka peneliti tertarik untuk meneliti tentang pendidikan inklusi. Penelitian yang dilakukan oleh peneliti memiliki persamaan dengan penelitian sebelumnya yaitu sama sama mengevaluasi program Pendidikan Inklusi.
Perbedaannya dengan penelitian-penelitian di atas adalah pada model evaluasi yang hendak digunakan, di mana penelitian ini menggunakan Model Evaluasi Kesenjangan (Discrepancy Evaluation Model).

Salah satu sekolah yang menerapkan program pendidikan inklusi adalah SMP Negeri 7 Salatiga. Namun dalam pelaksanaannya mengalami beberapa hambatan diantara masih kurangnya SDM dalam proses pembelajaran selaku GPK, guru-guru belum memiliki keahlian khusus dan masih kurang mendapatkan sosialisasi untuk menangani anak berkebutuhan khusus. Sarana dan prasarana yang tersedia masih belum menunjang kegiatan pembelajaran yang terdapat anak berkebutuhan khusus. Kurikulum juga belum dimodofikasi untuk dapat memberikan pembelajaran yang sesuai dengan semua kebutuhan siswa, selain itu penilaian juga belum mewakili kondisi siswa. Sekolah juga belum memiliki JUKNIS untuk menangani anak berkebutuhan khusus. Dengan banyaknya hambatan yang dihadapi sekolah dan belum pernah dilakukan evaluasi program pendidikan inklusi di SMP N 7 Salatiga, maka peneliti melakukan penelitian evaluasi program pendidikan inklusi.

Menurut Widoyoko (2013:10) evaluasi program merupakan rangkaian kegiatan yang dilakukan dengan sengaja dan secara cermat untuk mengetahui tingkat keterlaksanaan atau keberhasilan suatu program dengan cara mengetahui efektifitas masing-masing komponennya, baik terhadap program yang sedang berjalan maupun program yang telah berlalu. Sejalan dengan hal ini Arikunto \& Jabar (2009: 18) menjelaskan bahwa evaluasi program adalah upaya untuk mengetahui tingkat keterlaksanaan suatu kebijaksanaan secara cermat dengan cara mengetahui efektivitas masing-masing komponennya. Selanjutnya Tayibnapis (2008: 24) menambahkan bahwa evaluasi program harus mengumpulkan informasi yang valid, informasi yang dapat dipercaya, informasi yang berguna 
untuk program yang dievaluasi. Dapat dipahami bahwa evaluasi program adalah rangkaian kegiatan dalam upaya untuk mengumpulkan informasi yang dilakukan dengan sengaja dalam tingkat keterlaksanaan secara cermat, valid dan dapat dipercaya serta berguna untuk di evaluasi, untuk mengetahui tingkat keberhasilan kebijakan suatu program dengan cara mengetahui efektivitas dari masing-masing komponen terhadap program yang sedang berjalan maupun program yang berlalu sehingga evaluasi dapat berjalan sesuai tujuan dan mendapat hasil yang maksimal.

\section{Model Kesenjangan (Discrepancy} Model) yang dikembangkan oleh Malcolm Provus (1971) dalam bukunya berjudul Discrepancy Evaluation. Provus percaya bahwa evaluasi merupakan suatu seni (arts) melukiskan ketimpangan antara standar kinerja dengan kinerja yang terjadi (Wirawan: 2011: 106). Komponen yang perlu diperhatikan pada evaluasi model kesenjangan menurut Malcolm Provus adalah: 1) desain merupakan kegiatan merumuskan program yang didalamnya melibatkan siswa, staff dan sumber daya yang ada untuk melakukan suatu aktivitas dalam mencapai tujuan. 2) instalasi merupakan rancangan yang menentukan sebuah program sebagai standar untuk mempertimbangkan langkah-langkah proses pelaksanaan program. 3) proses merupakan kegiatan memperoleh data tentang sejauh mana program telah berjalan dalam mencapai tujuan yang diharapkan. 4) produk merupakan hasil dari tujuan program yang telah dicapai. 5) analisis biaya dan manfaat merupakan suatu kegiatan membandingkan penggunaan biaya yang dikeluarkan dengan hasil yang dicapai (Rose \& Nyre, 1977: 15). Pada penelitian ini, tidak dilakukan analisis biaya dan manfaat.

Berdasarkan latar belakang diatas, maka tujuan dari penelitian adalah untuk mengevaluasi desain, instalasi, proses dan produk pelaksanaan program pendidikan inklusi di SMP Negeri 7 Salatiga.

\section{METODE PENELITIAN}

Penelitian ini adalah penelitian evaluasi dengan pendekatan kualitatif. Model evaluasi yang digunakan adalah model evaluasi kesenjangan yang mencakup 4 (empat) tahap yaitu tahap desain, instalasi, proses dan tahap produk. Penelitian dilakukan di SMP Negeri 7 Salatiga. Sumber informasi dalam penelitian ini dalam Kepala Sekolah, Guru MULOK selaku GPK, dan guru BK selaku GPK. Teknik pengumpulan data yang digunakan meliputi wawancara, observasi dan studi dokumen. Teknik validasi data menggunakan teknik triangulasi sumber dan triangulasi teknik. Teknik analisis data menggunakan teknik analisis data kualitatif model Miles dan Huberman yang meliputi reduksi data, penyajian data, dan penarikan kesimpulan (Sugiyono, 2015: 404-412).

\section{HASIL PENELITIAN DAN PEMBAHASAN \\ Hasil Penelitian}

Hasil evaluasi terhadap desain, instalasi, proses dan produk program inklusi di SMP Negeri ini tergambar sebagai berikut ini.

\section{Evaluasi Desain Program Inklusi}

Pada tahap disain ditemukan bahwa tidak terdapat kesenjangan pada aspek tujuan, dan peserta didik, namun terdapat kesenjangan pada aspek assesmen, kurikulum, tenaga pendidik, rencana kegiatan pembelajaran, sarana dan prasara pendidikan serta dukungan masyarakat. Gambaran tentang ketiadaan kesenjangan dan adanya kesenjangan pada tahap desain tersebut tertera dalam tabel 1 berikut ini. 
Kelola: Jurnal Manajemen Pendidikan, Vol. 5, No. 2, Juli-Desember 2018

Tabel 1. Hasil Evaluasi pada Tahap Desain

\begin{tabular}{lllll}
\hline No & Komponen & \multicolumn{1}{c}{$\begin{array}{c}\text { Standar } \\
\text { Permendiknas }\end{array}$} & \multicolumn{1}{c}{$\begin{array}{c}\text { Kinerja } \\
\text { SMP N 7 Salatiga }\end{array}$} & Kesenjangan \\
\hline 1 & Tujuan & $\begin{array}{l}\text { Memberikan kesempatan, tidak } \\
\text { ada diskriminasi }\end{array}$ & $\begin{array}{l}\text { Bersosialisasi dengan sesama, mendapat } \\
\text { hak pendidikan yang sama }\end{array}$ & $\begin{array}{l}\text { Tidak ada } \\
\text { kesenjangan }\end{array}$ \\
\hline 2 & Peserta didik & $\begin{array}{l}\text { Anak normal dan ABK di } \\
\text { sekolah yang sama }\end{array}$ & $\begin{array}{l}\text { Anak normal dan anak berkebutuhan } \\
\text { khusus belajar di Sekolah Formal }\end{array}$ & $\begin{array}{l}\text { Tidak ada } \\
\text { kesenjangan }\end{array}$ \\
\hline 3 & Assesmen & $\begin{array}{l}\text { Penilaian Khusus bagi anak } \\
\text { berkebutuhan khusus }\end{array}$ & $\begin{array}{l}\text { Belum ada rencana penilaian khusus bagi } \\
\text { anak berkebutuhan khusus }\end{array}$ & $\begin{array}{l}\text { Terdapat } \\
\text { kesenjangan }\end{array}$ \\
\hline 4 & Kurikulum & $\begin{array}{l}\text { Modifikasi kurikulum bagi } \\
\text { Sekolah yang memiliki ABK }\end{array}$ & $\begin{array}{l}\text { Belum ada rencana modifikasi kurikulum } \\
\text { bagi ABK }\end{array}$ & $\begin{array}{l}\text { Terdapat } \\
\text { Kesenjangan }\end{array}$ \\
\hline 5 & $\begin{array}{l}\text { Tenaga } \\
\text { Pendidik }\end{array}$ & $\begin{array}{l}\text { Memiliki kompetensi untuk } \\
\text { menangani ABK }\end{array}$ & $\begin{array}{l}\text { Guru masih mengalami kesulitan dalam } \\
\text { menangani ABK }\end{array}$ & $\begin{array}{l}\text { Terdapat } \\
\text { kesenjangan }\end{array}$ \\
\hline 6 & $\begin{array}{l}\text { Rencana } \\
\text { Kegiatan }\end{array}$ & $\begin{array}{l}\text { Pembelajaran dikembangkan } \\
\text { sesuai kebutuhan siswa }\end{array}$ & $\begin{array}{l}\text { Belum ada pengembangan rencana } \\
\text { pembelajaran khusus dan } \\
\text { menggunakan metode umum }\end{array}$ & $\begin{array}{l}\text { Terdapat } \\
\text { kesenjangan }\end{array}$ \\
\hline 7 & $\begin{array}{l}\text { Sarana } \\
\text { Prasarana }\end{array}$ & $\begin{array}{l}\text { Sarana dan prasarana harus } \\
\text { memenuhi kebutuhan siswa, } \\
\text { terutama untuk ABK }\end{array}$ & $\begin{array}{l}\text { Sarana dan prasarana untuk kebutuhan } \\
\text { anak berkebutuhan khusus masih kurang } \\
\text { memadai }\end{array}$ & $\begin{array}{l}\text { Terdapat } \\
\text { kesenjangan }\end{array}$ \\
\hline 8 & Pembiayaan & $\begin{array}{l}\text { Mendapat dana dari pemerin } \\
\text { tah, masyarakat \& orangtua }\end{array}$ & $\begin{array}{l}\text { Menggunakan dana BOS dan sebagian } \\
\text { dana dari orangtua ABK }\end{array}$ & $\begin{array}{l}\text { Terdapat } \\
\text { kesenjangan }\end{array}$ \\
\hline
\end{tabular}

Sumber: Permendiknas No 70 Tahun 2009 \& Data Penelitian

\section{Evaluasi Instalasi Program Inklusi}

Pada tahap disain ditemukan kesenjangan pada seluruh aspek instalasi.
Gambaran tentang adanya kesenjangan pada tahap instalasi tersebut tertera dalam tabel 2 berikut ini.

Tabel 2 . Hasil Evaluasi pada Tahap Instalasi

\begin{tabular}{|c|c|c|c|c|}
\hline No & Komponen & $\begin{array}{c}\text { Standar } \\
\text { Permendiknas } \\
\end{array}$ & $\begin{array}{c}\text { Kinerja } \\
\text { SMP N } 7 \text { Salatiga } \\
\end{array}$ & Kesenjangan \\
\hline 1 & Peserta didik & $\begin{array}{l}\text { Sekolah menerima anak normal dan } \\
\text { ABK. Untuk mendeteksi dilakukan } \\
\text { tes masuk }\end{array}$ & $\begin{array}{l}\text { Sekolah menerima anak normal dan } \\
\text { ABK. Tidak ada tes yang dirancang } \\
\text { saat penerimaan peserta didik }\end{array}$ & $\begin{array}{l}\text { Terdapat } \\
\text { kesenjangan }\end{array}$ \\
\hline 2 & $\begin{array}{l}\text { Assesmen } \\
\text { pembelajaran }\end{array}$ & $\begin{array}{l}\text { Assesmen dilakukan untuk } \\
\text { mengetahui kondisi ABK meliputi } \\
\text { aspek kompetensi, potensi dan } \\
\text { karakteristik siswa }\end{array}$ & $\begin{array}{l}\text { Belum adanya rencana pelaksanaan } \\
\text { dalam assesmen pembelajaran } \\
\text { terkhusus untuk ABK }\end{array}$ & $\begin{array}{l}\text { Terdapat } \\
\text { kesenjangan }\end{array}$ \\
\hline 3 & Kurikulum & $\begin{array}{l}\text { Kurikulum dirancang } \text { berdasarkan } \\
\text { standar nasional r dengan } \\
\text { dimodifikasi sesuai kebutuhan dan } \\
\text { kemampuan siswa }\end{array}$ & $\begin{array}{l}\text { Belum adanya rencana pelaksanaan } \\
\text { untuk modifikasi kurikulum, hanya } \\
\text { adanya rencana program layanan } \\
\text { tentang keterampilan bagi ABK }\end{array}$ & $\begin{array}{l}\text { Terdapat } \\
\text { kesenjangan }\end{array}$ \\
\hline 4 & $\begin{array}{l}\text { Tenaga } \\
\text { pendidik }\end{array}$ & $\begin{array}{l}\text { Pemerintah menyediakan SDM dan } \\
\text { meningkatkan kompetensi nya }\end{array}$ & $\begin{array}{l}\text { Dinas hanya menunjuk } 2 \text { GPK dan } \\
\text { untuk meningkatkan kompetensi guru } \\
\text { dan GPK masih minim }\end{array}$ & $\begin{array}{l}\text { Terdapat } \\
\text { kesenjangan }\end{array}$ \\
\hline 5 & $\begin{array}{l}\text { Rancangan } \\
\text { pembelajaran }\end{array}$ & $\begin{array}{l}\text { Rencana pembelajaran } \\
\text { dikembangkan dengan } \\
\text { mempertimbangkan perbedaan } \\
\text { individu }\end{array}$ & $\begin{array}{l}\text { Belum adanya rencana pelaksanaan } \\
\text { metode pembelajaran bagi ABK dan } \\
\text { belum mempertimbangkan perbedaan } \\
\text { individu }\end{array}$ & $\begin{array}{l}\text { Terdapat } \\
\text { kesenjangan }\end{array}$ \\
\hline 6 & $\begin{array}{l}\text { Sarana dan } \\
\text { prasarana }\end{array}$ & $\begin{array}{l}\text { Sarpras harus bersifat aksesibel, } \\
\text { sehingga ABK dapat belajar } \\
\text { dengan baik }\end{array}$ & $\begin{array}{l}\text { Belum adanya rencana pelaksanaan } \\
\text { untuk penyediaan sarpras bersifat } \\
\text { aksesibel sehingga guru mengalami } \\
\text { kendala saat mengajar }\end{array}$ & $\begin{array}{l}\text { Terdapat } \\
\text { kesenjangan }\end{array}$ \\
\hline 7 & Pembiayaan & $\begin{array}{l}\text { Pembiayaan harus ditanggaung } \\
\text { bersama antara pemerintah, } \\
\text { masyarakat dan orangtua }\end{array}$ & $\begin{array}{l}\text { Pembiayaan hanya diambil dari dana } \\
\text { BOS dan dukungan biaya dari } \\
\text { sebagian orangtua ABK }\end{array}$ & $\begin{array}{l}\text { Terdapat } \\
\text { kesenjangan }\end{array}$ \\
\hline
\end{tabular}

Sumber: Permendiknas No 70 Tahun 2009 \& Data Penelitian 


\section{Evaluasi Proses Program Inklusi}

Pada tahap proses ditemukan bahwa terdapat kesenjangan pada seluruh aspek proses pendidikan inklusi yang meliputi kegiatan belajar siswa, kegiatan mengajar guru, kegiatan pembelajaran, sarana dan prasara pendidikan serta dukungan masyarakat. Gambaran tentang adanya kesenjangan pada tahap proses pendidikan inklusi tersebut tertera dalam tabel 3 berikut ini.

Tabel 3. Hasil Evaluasi pada Tahap Proses

\begin{tabular}{|c|c|c|c|c|}
\hline No & Komponen & $\begin{array}{l}\text { Standar } \\
\text { Permendiknas }\end{array}$ & $\begin{array}{l}\text { Kinerja } \\
\text { SMP N } 7 \text { Salatiga }\end{array}$ & Kesenjangan \\
\hline 1 & $\begin{array}{l}\text { Kegiatan belajar } \\
\text { siswa }\end{array}$ & $\begin{array}{l}\text { ABK belajar bersama anak } \\
\text { normal dan memperoleh layanan } \\
\text { khusus dari guru GPK }\end{array}$ & $\begin{array}{l}\text { ABK dan anak normal belajar } \\
\text { bersama. Terkadang ABK } \\
\text { mengalami kesulitan karena tidak } \\
\text { mendapatkan layanan khusus saat } \\
\text { proses pembelajaran berlangsung }\end{array}$ & $\begin{array}{l}\text { Terdapat } \\
\text { kesenjangan }\end{array}$ \\
\hline 2 & $\begin{array}{l}\text { Kegiatan } \\
\text { mengajar guru }\end{array}$ & $\begin{array}{l}\text { Guru kelas menerapkan } \\
\text { pembelajaran sesuai kebutuhan } \\
\text { siswa } \\
\text { GPK mendampingi anak } \\
\text { berkebutuhan khusus }\end{array}$ & $\begin{array}{l}\text { Guru memberikan materi } \\
\text { pembelajaran secara umum dan } \\
\text { belum didesain dengan } \\
\text { mempertimbangkan adanya ABK } \\
\text { GPK belum bisa sepenuhnya } \\
\text { melakukan pendampingan terhadap } \\
\text { ABK }\end{array}$ & $\begin{array}{l}\text { Terdapat } \\
\text { kesenjangan }\end{array}$ \\
\hline \multirow{3}{*}{3} & \multirow{3}{*}{$\begin{array}{l}\text { Kegiatan } \\
\text { pembelajaran }\end{array}$} & $\begin{array}{l}\text { Kegiatan pembelajaran harus } \\
\text { sesuai kebutuhan siswa dengan } \\
\text { setting kelas inklusi }\end{array}$ & $\begin{array}{l}\text { ABK mendapat dan mengikuti } \\
\text { materi yang sama dengan anak } \\
\text { normal. }\end{array}$ & \multirow{3}{*}{$\begin{array}{l}\text { Terdapat } \\
\text { kesenjangan }\end{array}$} \\
\hline & & $\begin{array}{l}\text { Menggunakan strategi variatif } \\
\text { dan PAKEM sesuai karakteristik } \\
\text { kebutuhan siswa }\end{array}$ & $\begin{array}{l}\text { Guru dapat memaklumi dengan } \\
\text { adanya ABK tapi kurang mendapat } \\
\text { perhatian khusus dari guru }\end{array}$ & \\
\hline & & $\begin{array}{l}\text { Guru melakukan proses } \\
\text { penilaian dan hasil belajar secara } \\
\text { beragam dan berkesinambungan } \\
\text { sesuai dengan kondisi siswa }\end{array}$ & $\begin{array}{l}\text { Proses penilaian diserahkan pada } \\
\text { GPK dan hasil penilaian belum } \\
\text { dibedakan dengan anak normal. }\end{array}$ & \\
\hline 4 & $\begin{array}{l}\text { Sarana } \\
\text { prasarana }\end{array}$ & $\begin{array}{l}\text { Penyediaan sarana dan prasarana } \\
\text { secara umum, namun harus } \\
\text { disediakan secara khusus yang } \\
\text { bersifat aksesibel untuk ABK }\end{array}$ & $\begin{array}{l}\text { Pemenuhan sarana dan prasarana } \\
\text { diambil dari dana BOS saat perlu } \\
\text { baru diajukan }\end{array}$ & $\begin{array}{l}\text { Terdapat } \\
\text { kesenjangan }\end{array}$ \\
\hline 5 & $\begin{array}{l}\text { Dukungan } \\
\text { masyarakat }\end{array}$ & $\begin{array}{l}\text { Berperan dalam perencanaan, } \\
\text { penyediaan tenaga ahli, } \\
\text { mengambil } \\
\text { pelaksanaan } \\
\text { pendanaan, peputusan, } \\
\text { penyaluran lulusan melajaran, } \\
\text { komite Sekolah, dewan } \\
\text { pendidikan dan forum-forum } \\
\text { pemerhati pendidikan inklusi }\end{array}$ & $\begin{array}{l}\text { Mendapat dukungan dari sebagian } \\
\text { orangtua ABK Menjalin kerjasama } \\
\text { dengan instansi, namun belum } \\
\text { maksimal. Komite belum } \\
\text { mengetahui tentang adanya program } \\
\text { pendidikan inklusi karena kepela } \\
\text { Sekolah belum menyampaikan }\end{array}$ & $\begin{array}{l}\text { Terdapat } \\
\text { kesenjangan }\end{array}$ \\
\hline
\end{tabular}

Sumber: Permendiknas No 70 Tahun 2009 \& Data Penelitian

\section{Evaluasi Produk Program Inklusi}

Pada tahap produk ditemukan adanya kesenjangan pada aspek rapot, namun tidak terdapat kesenjangan pasa aspek hasil belajar dan ijazah. Perlu dicatat bahwa untuk aspek ujian dan lulusan belum dapat dilakukan evaluasi karena sampai saat penelitian dilakukan belum ada anak berkebutuhan khusus yang mengikuti ujian sekolah, sehingga belum ada juga lulusan. Gambaran tentang ketiadaan kesenjangan dan adanya kesenjangan pada tahap produk tersebut tertera dalam tabel 4 berikut ini. 
Kelola: Jurnal Manajemen Pendidikan, Vol. 5, No. 2, Juli-Desember 2018

Tabel 4. Kesenjangan Pada Tahap Produk

\begin{tabular}{|c|c|c|c|c|}
\hline No & Komponen & $\begin{array}{l}\text { Standar } \\
\text { Permendiknas }\end{array}$ & $\begin{array}{l}\text { Kinerja } \\
\text { SMP N } 7 \text { Salatiga }\end{array}$ & Kesenjangan \\
\hline 1 & Hasil belajar & $\begin{array}{l}\text { Kenaikan kelas berdasarkan } \\
\text { standar Sekolah }\end{array}$ & $\begin{array}{l}\text { Anak berkebutuhan khusus tetap naik } \\
\text { kelas dan tidak ada kata tinggal kelas }\end{array}$ & $\begin{array}{l}\text { Tidak ada } \\
\text { kesenjangan }\end{array}$ \\
\hline 2 & Rapot & $\begin{array}{l}\text { Penilaian untuk rapot bagi anak } \\
\text { berkebutuhan khusus berbeda } \\
\text { dengan anak normal }\end{array}$ & $\begin{array}{l}\text { Penilaian untuk rapot anak berkebutuhan } \\
\text { khusus masih sama dengan anak normal }\end{array}$ & $\begin{array}{l}\text { Terdapat } \\
\text { kesenjangan }\end{array}$ \\
\hline 3 & Ujian & $\begin{array}{l}\text { Anak berkebutuhan khusus } \\
\text { mengikuti ujian Sekolah }\end{array}$ & $\begin{array}{l}\text { Anak berkebutuhan khusus mengikuti } \\
\text { ujian Sekolah }\end{array}$ & n.a \\
\hline 4 & Ijazah & $\begin{array}{lr}\text { Anak berkebutuhan khusus } \\
\text { mendapatkan ijazah } \\
\text { Sekolah }\end{array}$ & $\begin{array}{l}\text { Anak berkebutuhan khusus mendapatkan } \\
\text { ijazah berupa surat tanda tamat belajar } \\
\text { yang blangkonya dikeluarkan Sekolah }\end{array}$ & $\begin{array}{l}\text { Tidak ada } \\
\text { kesenjangan }\end{array}$ \\
\hline 5 & Lulusan & $\begin{array}{l}\text { Anak berkebutuhan khusus } \\
\text { yang lulus Sekolah mendapat } \\
\text { surat keterangan dan ijazah } \\
\text { untuk melanjutkan pada jenjang } \\
\text { yang lebih tinggi }\end{array}$ & $\begin{array}{l}\text { Belum adanya lulusan anak berkebutuhan } \\
\text { khusus dan masih menjadi problematis } \\
\text { bagi Sekolah tentang kelanjutan anak } \\
\text { berkebutuhan khusus pada jenjang lebih } \\
\text { tinggi }\end{array}$ & n.a \\
\hline
\end{tabular}

Sumber: Permendiknas No 70 Tahun 2009 \& Data Penelitian

\section{Pembahasan}

Pada evaluasi tahap desain secara umum tujuan penyelenggaraan program pendidikan inklusi di lokasi penelitian sama seperti acuan yang ada yaitu memberikan kesempatan kepada seluruh peserta didik untuk belajar bersama sehingga tidak adanya diskriminasi, sasaran peserta didik inklusi adalah anak berkebutuhan khusus untuk dapat belajar secara bersamasama dengan siswa normal di Sekolah regular. Karena memang seharusnya sistem layanan pendidikan inklusi terbuka untuk semua siswa dan tidak membeda-bedakan latar belakang kehidupan siswa, serta memberikan kesempatan yang sama untuk belajar, tidak ada diskriminasi, memberikan hak dan kesempatan yang sama, memberikan keadilan dan perluasan akses bagi semua. Desain penyelenggaraan inklusi itu sejalan dengan pendapat Ahsan (2014), Ilahi (2013), Wathoni (2005), dan Kustawan ( 2012) yang menyatakan bahwa pendidikan inklusi dirancang dengan mempertimbangkan kebutuhan siswa baik yang normal dan penyandang cacat atau anak berkebutuhan khusus. Namun demikian ditemukan pula kesenjangan pada tahap desain yaitu dalam aspek sistem assesmen pembelajaran karena belum ada rencana secara umum penilaian khusus untuk anak berkebutuhan khusus. Di samping itu sekolah masih menggunakan kurikulum nasional dan belum ada rencana modifikasi kurikulum. Temuan ini, untuk sebagian sejalan dengan hasil penelitian Sari (2012), yang menyatakan bahwa pelaksanaan inklusi di SD Negeri tempat penelitiannya, tidak berjalan sebagai mana mestinya. Jadi temuan ini berbeda dengan pandangan Muftuhatin (2014 yang menyatakan bahwa seharusnya kurikulum nasional dimodifikasi sesuai dengan kebutuhan siswa, agar anak berkebutuhan khusus dapat mengikuti pembelajaran seperti siswa normal lainnya. Dalam modifikasi diperlukan kerjasama antara guru, GPK, orangtua, para professional dan peserta didik. Kerjasama dilakukan untuk memodifikasi program kerja penetapan tujuan, isi, strategi, metode pembelajaran, organisasi kelas, assesmen, evaluasi, komunikasi dan pembiayaan.

Dari aspek tenaga pendidik, tenaga pendidik di sekolah ini belum memiliki kompetensi yang tepat untuk menangani anak berkebutuhan khusus. Rencana dalam kegiatan pembelajaran belum dikembangkan sehingga metode pembelajaran masih secara umum dan belum ada rencana dengan metode pembelajaran khusus bagi ABK. Hal itu berbeda dengan aturan Kemendikbud (2012) maupun pendapat Kustawan (2012) yang menyatakan bahwa Guru adalah pihak yang paling berperan penting dalam pelaksanaan pembelajaran di kelas, sehingga guru harus 
memenuhi kualifikasi dan kompetensi yang tepat untuk melakukan proses pembelajaran dengan menyesuaikan kebutuhan seluruh siswa dan mampu menangani anak berkebutuhan khusus.

Rencana sekolah dalam penyediaan sarana dan prasarana juga masih kurang memadai untuk menjamin kebutuhan ABK di sekolah. Hal itu tidak sejalan dengan pandangan Kustawan (2012) yang mengatakan bahwa pendidikan inklusi hendaknya menyediakan sarana dan prasarana yang memadai untuk menjamin kebutuhan siswa dan anak berkebutuhan khusus dapat mengikuti pembelajaran dengan siswa normal lainnya. Juga tidak sejalan dengan Permendiknas No 70 Tahun 2009 pasal 11 yang menentukan bahwa sekolah harus menyediakan sarana dan prasarana yang aksesibel agar anak berkebutuhan khusus dapat mengikuti pembelajaran dengan baik.

Sekolah hanya mendapat dukungan pelaksanaan dari orangtua anak berkebutuhan khusus dan beberapa instansi. Padahal pendidikan merupakan tanggung jawab bersama antara sekolah, mayarakat dan pemerintah. Masyarakat juga harus berperan dalam perencanaan, penyediaan tenaga ahli, pengambilan keputusan, pelaksanaan pembelajaran, pendanaan, pengawasan dan penyaluran lulusan. Temuan ini menunjukkan bahwa sekolah belum sepenuhnya mampu melaksanakan Permendiknas No 70 Tahun 2009 yang menentukan bahwa dalam penyelenggaraan program pendidikan inklusi Sekolah dapat bekerjasama dan membangun jaringan dengan satuan pendidikan khusus, perguruan tinggi, organisasi profesi, lembaga rehabilitasi, rumah sakit, pusat kesehatan masyarakat, terapi klinik, LSM dan masyarakat.

Terdapat kesenjangan dalam tahap instalasi pada komponen peserta didik, karena sekolah tidak memiliki tes yang dirancang secara umum saat penerimaaan peserta didik baru. Di samping itu dalam sistem assesemen pembelajaran juga belum ada rancangan penilaian khusus bagi ABK. Temuan ini menunjukkan bahwa sekolah belum mampu sepenuhnya melaksanakan ketentuan Permendiknas No 70 Tahun 2009 yang menetapkan bahwa sistem assesmen pembelajaran seharusnya dirancang untuk mengetahui kondisi siswa, dimana assesmen pembelajaran meliputi tahap perencanaan, pengumpulan informasi untuk mencapai hasil belajar, pelaporan dan penggunaan informasi hasil belajar siswa. Assesmen meliputi penilaian tertulis, sikap, kinerja atau produk, portofolio dan unjuk kerja.

Terdapat kesenjangan yang terjadi pada tahapan proses yaitu dalam hal kegiatan belajar siswa, di mana anak berkebutuhan khusus masih mengalami kesulitan dalam proses pembelajaran karena siswa tidak mendapatkan layanan khusus saat proses pembelajaran berlangsung. Temuan ini berbeda dengan pandangan Zakia (2015) dan Muftuhatin (2012) yang menyatakan bahwa seharusnya pendidikan inklusi membantu siswa untuk mengatasi hambatan-hanbatan siswa dalam belajar. Maka dari itu proses pelaksanaan pendidikan inklusi memerlukan penyesuaian dan fleksibilitas baik dalam bidang pendidikan, pengajaran, sosial, perilaku dan budaya

Pada kegiatan mengajar guru masih menggunakan materi atau bahan ajar secara umum dan belum rancangan yang didesain dengan mempertimbangkan adanya anak berkebutuhan khusus dan GPK belum bisa sepenuhnya melakukan pendampingan terhadap anak berkebutuhan khusus. Saat kegiatan pembelajaran anak berkebutuhan khusus masih mengikuti dan mendapatkan materi yang sama dengan siswa normal, guru memaklumi adanya anak berkebutuhan khusus tapi tidak untuk dikembangkan, serta untuk proses penilaian bagi anak berkebutuhan khusus juga masih disamakan dengan siswa normal. Temuan ini berbeda dari arahan 
Kelola: Jurnal Manajemen Pendidikan, Vol. 5, No. 2, Juli-Desember 2018

Direktorat PPK-LK (2011) bahwa guru atau pendidik seharusnya memberikan pendampingan, bukan hanya menjadi tanggung jawab guru GPK saja. Karena dalam penyelenggaraan program pendidikan inklusi semua pihak di Sekolah harus melakukan penyesuaian baik dari segi kurikulum, sarana dan prasarana dan sistem pembelajaran yang disesuaikan dengan kebutuhan dan karakteristik anak berkebutuhan khusus. Temuan ini sejalan dengan penelitian Mitiku, dkk (2014) bahwa meskipun ada beberapa peluang yang mendukung pendidikan inklusi, namun kurangnya kesadaran dan kerjasama hal itu tidak dapat dianggap sebagai jaminan terselenggaranya program pendidikan inklusi.

Evaluasi pada tahap produk menunjukkan bahwa Sekolah telah membuat penetapan khusus bahwa ABK tidak akan pernah tinggal kelas. Temuan ini sejalan dengan pandangan Ilahi (2013: 25) yang mengatakan bahwa pendidikan inklusi harus dimaknai sebagai bentuk reformasi pendidikan yang menekankan sikap anti diskriminasi, perjuangan persamaan hak dan kesempatan, keadilan dan perluasan akses bagi semua, serta mengubah pandangan sikap masyarakat terhadap anak berkebutuhan khusus. Temuan di atas mendukung temuan penelitian Lukitasari, dkk (2017) yang menunjukkan bahwa impelementasi kebijakan pendidikan inklusi di kota Salatiga dinilai baik terlihat dari meningkatnya jumlah peserta didik ABK dan kurangnya diskriminasi terhadap siswa ABK. Temuan ini juga sejalan dengan hasil penelitian Sartica dan Ismanto (2016), yang menemukan bahwa prestasi akademik dan non akademik adalah siswa dengan kebutuhan khusus di lokasi penelitian mereka cukup baik.

Namun demikian ditemukan pula adanya fakta bahwa penilaian untuk rapot bagi anak berkebutuhan khusus masih sama dengan penilaian bagi siswa normal. Fakta tersebut berbeda dengan Permendiknas No 70 Tahun 2009 yang menentukan bahwa seharusnya sistem hasil belajar sekolah inklusi berupa angka-angka disertai narasi penguasaan materi. Untuk itu Sekolah yang menyelenggarakan program pendidikan inklusi harus memodifikasi sistem penilaiannya dengan mempertimbangkan kondisi anak berkebutuhan khusus.

\section{SIMPULAN DAN SARAN \\ Simpulan}

Berdasarkan hasil penelitian yang telah dilakukan, maka dapat diambil kesimpulan bahwa pada tahap desain, tujuan penyelenggaraan program pendidikan inklusi dan peserta didik inklusi sama dengan acuan yang ada yaitu memberikan kesempatan yang sama tanpa adanya diskriminasi serta sasaran peserta didik inklusi adalah ABK. Kesenjangan yang ditemukan adalah belum adanya rencana dalam sistem assesmen pembelajaran, penilaian dan modifikasi kurikulum. Disamping itu tenaga pendidik belum memiliki kompetensi yang tepat menangai $\mathrm{ABK}$, sementara sarana dan prasarana yang ada juga kurang memadai bagi ABK.

Pada tahap instalasi, terdapat kesenjangan karena pada saat penerimaan peserta didik baru tidak dilakukan tes masuk, dalam rancangan pembelajaran dan rancangan penilaian belum dilakukan modifikasi dengan mempertimbangkan ABK, belum ada pembelajaran tambahan berupa pembekalan keterampilan untuk ABK, pembiayaan untuk pelaksanaan program hanya diambil dari dana BOS dan dukungan dari sebagian orang tua ABK.

Pada tahap proses, terdapat kesenjangan bahwa ABK masih mengalami kesulitan dalam mengikuti pembelajaran, karena pelaksanaan pembelajaran belum mempertimbangkan keadaan ABK dan penilaian hasil belajar ABK masih disamakan dengan siswa normal. Dukungan dari masyarakat dan beberapa instansi juga belum maksimal. Sedangkan di tahap produk kesenjangan terdapat pada hasil 
Evaluasi Pelaksanaan Program Pendidikan Inklusi di SMP Negeri | Eni Mariani \& Bambang S. Sulasmono

belajar siswa dalam penilaian rapot yang masih sama dengan siswa normal.

\section{Saran}

Dari penelitian evaluasi yang telah dilakukan, maka peneliti memberikan rekomendasi untuk perbaikan program, sebagai berikut: 1) guru saling bekerjasama dalam pengembangan kurikulum dan alat evaluasi sehingga dapat menyelenggarakan pembelajaran yang lebih sesuai dengan kebutuhan ABK. Selain itu guru juga perlu meningkatkan kompetensinya dalam menangani ABK; 2) Kepala Sekolah perlu memberikan ruang yang dapat digunakan untuk memberikan pelayanan terbaik bagi ABK, meningkatkan pengembangan diri para guru dan GPK, merancang model dan petunjuk teknis untuk menangani berbagai kriteria $\mathrm{ABK}$, serta memaksimalkan jalinan kerjasama dengan beberapa instansi; 3) Dinas Pendidikan perlu membangun komunikasi dan melakukan pembinaan serta pengawasan pada Sekolah yang menyelenggarakan program pendidikan inklusi. Dinas juga perlu menambah GPK yang khusus menangani ABK, memberikan dukungan maksimal dalam pengembangan kompetensi guru dan GPK, memperhatikan pelaksanaan program pendidikan inklusi dan memberikan bantuan baik berupa biaya, pelatihan, seminar maupun pemenuhan sarana dan prasarana.

\section{UCAPAN TERIMAKASIH}

Terimakasih yang tulus diberikan kepada Dr. Ade Iriani, MM yang menjadi Pembimbing I dalam penulisan Tesis yang substansinya kemudian tersaji dalam bentuk artikel ini.

\section{DAFTAR PUSTAKA}

Ahsan, M. T. 2014. "Inclusive Education: A Strategy to Address Diversity to Ensure Equal Right to Education. Editorial". Asian Journal of Inclusive Education (AJIE). Vo.2, No.1, April 2014, 1-3.
Alfian. 2013. Pendidikan Inklusif di Indonesia. Edu-Bio. Vol. 4.

Arikunto, S., \& Jabar, C. S. A. 2009. Evaluasi Program Pendidikan: Pedoman Teoritis Praktis Bagi Mahasiswa dan Praktisi Pendidikan. Jakarta: Bumi Aksara

Direktorat Pembinaan PKLK Pendidikan Dasar. 2012. Permendiknas Nomor 70 Tahun 2009. Jakarta: Direktorat Jenderal Pendidikan Dasar Kementerian Pendidikan dan Kebudayaan.

Ilahi, Muhammad Takdir. 2013. Pendidikan Inklusif. Jogjakarta: Ar-Ruzz Media.

Kemendikbud. 2009. Permendiknas Nomor 70 Tahun 2009 Tentang Pendidikan Inklusif Bagi Peserta Didik yang Memiliki Kelainan dan Memiliki Potensi Kecerdasan dan/atau Bakat Istimewa. Kemendikbud: Jakarta.

Kustawan, Dedy. 2012. Pendidikan Inklusif \& Upaya Implementasinya. Jakarta: PT. Luxima Metro Media.

Lukitasari, S., Sulasmono, B., \& Iriani, A. 2017. Evaluasi Implementasi Kebijakan Pendidikan Inklusi. Kelola: Jurnal Manajemen Pendidikan, 4(2), 121-134. https://doi.org/https://doi.org/10.24246/ j.jk.2017.v4.i2.p121-134.

Maftuhatin, Lilik. 2014. Evaluasi pembelajaran anak berklebutuhan khusus (ABK) di kelas inklusif di SD Plus Darul 'Ulum Jombang. Jurnal Studi Islam. Volume 5. 201-227.

Mitiku, M., Yitayal, A., Semahegn, M., 2014. Challenges and Opportunities to Implement Inclusive Education. Asian Journal of Humanity, Art and Literature, Volume 1 (2) 118-135.

Rose Clare \& Glenn F. Nyre. 1977. The Practice of Evaluation. Princetion: 
Kelola: Jurnal Manajemen Pendidikan, Vol. 5, No. 2, Juli-Desember 2018

Education Testing Service; Princeton, New Jersey: ERIC/TM Report 65.

Sari, W. Quida. 2012. Pelaksanaan inklusi di Sekolah Dasar Negeri 14 Pakan Sinayan Payakumbuh. Jurnal Ilmiah Pendidikan Khusus. Volume (1) 190-197.

Sartica, D., \& Ismanto, B. 2016. Evaluasi Penyelenggaraan Program Pendidikan Inklusif di Kota Palangka Raya 1. Kelola: Jurnal Manajemen Pendidikan, 3(1), 49-66. https://doi.org/https://doi.org/10.24246/ j.jk.2016.v3.i1.p49-66

Sugiyono. 2015. Metode Penelitian Manajemen. Bandung: Alfabeta.

Sunardi. Mucawir, Y., Gunarhadi. Proyono. John, L., Yeager. 2011. The implementation of inclusive education for students with special needs in Indonesia. Excellence in Higher education. Volume 2. 1-10.

Tayibnapis, Yusuf. F. 2008. Evaluasi Program dan Instrumen Evaluasi untuk Program Pendidikan dan Penelitian. Jakarta: Rineka Cipta.
Wathoni, Khasirul. 2005. Implementasi Pendidikan Inklusi Dalam Pendidikan Islam. Ta'allum. Volume 01. 99-109.

Widoyoko, Eko, Putro. 2013. Evaluasi Program Pembelajaran: Panduan Praktis Bagi Pendidik dan Calon Pendidik. Yogyakarta: Pustaka Pelajar.

Widyawati, R. 2017. Evaluasi Pelaksanaan Program Inklusi Sekolah Dasar. Kelola: Jurnal Manajemen Pendidikan, 4(1), 109-120. https://doi.org/https://doi.org/10.24246/ j.jk.2017.v4.i1.p109-120.

Wirawan. 2012. Evaluasi: Teori, Model, Standar, Aplikasi dan Profesi. Jakarta: Raja Grafindo Persada.

Zakia, Dieni, Laylatul. 2015. Guru Pembimbing Khusus (GPK): Pilar Pendidikan Inklusi: Prosiding Seminar Nasional Pendidikan: Meretas Sukses Publikasi Ilmiah Bidang Pendidikan Jurnal Bereputasi. Surakarta, 21 November 2015 